\title{
Examining a Most Likely Case for Strong Campaign Effects: Hitler's Speeches and the Rise of the Nazi Party, 1927-1933*
}

\author{
Forthcoming at American Political Science Review
}

\author{
Peter Selb (corresponding author) \\ University of Konstanz \\ Department of Politics and Public Administration \\ P.O. Box 85 \\ D-78457 Konstanz, Germany \\ +49 (0)7531 88-2321 \\ peter.selb@uni.kn \\ Simon Munzert \\ Hertie School of Governance \\ Friedrichstr. 180 \\ D-10117 Berlin, Germany \\ +49(0)30259219450 \\ munzert@hertie-school.org
}

\footnotetext{
${ }^{*}$ We are grateful to Johannes Häussler and Sascha Göbel for their superb research assistance; Fred Hockney for his proof-reading and language editing; Birgit Jacob and Hannah Laumann for their editing; Christian Spinner, who sounded out the terrain in his Bachelor's thesis; Jürgen W. Falter, Jonas Meßner, Dieter Ohr, and Paul Thurner, who provided their data; the participants of the research colloquium of the Graduate School of Decision Sciences at the University of Konstanz; the panel on media and politics at the EPSA Conference 2016 in Brussels; Alexander De Juan, Thomas Gschwend, Moritz Marbach and the reviewers for valuable comments; and the responsible editor for his enduring support during a long and controversial review process.
} 


\begin{abstract}
Hitler's rise to power amidst an unprecedented propaganda campaign initiated scholarly interest in campaign effects. To the surprise of many, empirical studies often found minimal effects. The predominant focus of early work was on U.S. elections, though. Nazi propaganda as the archetypal and, in many ways, most likely case for strong effects has rarely been studied. We collect extensive data about Hitler's speeches and gauge their impact on voter support at five national elections preceding the dictatorship. We use a semi-parametric difference-in-differences approach to estimate effects in the face of potential confounding due to the deliberate scheduling of events. Our findings suggest that Hitler's speeches, while rationally targeted, had a negligible impact on the Nazis' electoral fortunes. Only the 1932 presidential runoff, an election preceded by an extraordinarily short, intense and one-sided campaign, yielded positive effects. This study questions the importance of charismatic leaders for the success of populist movements.
\end{abstract}


"I am conscious that I have no equal in the art of swaying the masses." -Adolf Hitler in a reported conversation (1932-34) with early co-partisan Hermann Rauschning $(1939,212)$. The authenticity of these records has been challenged; see Janssen (1985).

\section{Prologue}

On November 11, 1923, almost ten years before the Nazi seizure of power, Adolf Hitler was arrested and subsequently sentenced to five years in prison for his leading role in the Beer Hall Putsch, a failed coup d'état against the national government. While detained, Hitler ordered the banned and disintegrating National Socialist German Workers' Party (Nationalsozialistische Deutsche Arbeiterpartei, NSDAP) to transform from a subversive battle group to a viable political party (Stachura, 1980). As Hitler put it in a personal conversation with Nazi fundraiser Kurt Lüdecke (quoted in Pridham, 1973, 27):

"Instead of working to achieve power by an armed coup, we shall have to hold our noses and enter the Reichstag [the national parliament] against the Catholic and Marxist deputies. If out-voting them takes longer than outshooting them, at least the results will be guaranteed by their own constitution."

Hitler was released on parole at the end of 1924 and caused the ban on the NSDAP to be lifted by affirming his party's new loyalty to the constitution. His previous assertions notwithstanding, Hitler held a rabble-rousing public speech at the party's re-launch on February 27, 1925 in Munich. The regional authorities' reaction came swiftly: five forthcoming public appearances were cancelled immediately, and on March 9, the Bavarian cabinet issued a two-year gag order against Hitler (Rösch, 2002, 56-68). Many other regional governments, including those of Prussia, Saxony, Hesse, Oldenburg, Anhalt, Hamburg, and Lübeck, followed (Bruppacher, 2012, 159-172). Although the NSDAP was not banned once again, party organs and meetings were subject to increased surveillance. According to police reports, turnout at NSDAP meetings and rallies declined markedly in the subsequent period (Rösch, 2002, 208-210), and the NSDAP's poor results at the state elections in Saxony, Mecklenburg-Schwerin, and Thuringia reinforced the view that "the NSDAP with a Hitler free to speak in public would cause no future concern to the authorities" (Pridham, 1973, 77). On March 6, 1927, the Bavarian government revoked its gag order, and Adolf Hitler would take up his unprecedented campaign activities. In the period of time between the repeal of the speaking ban on March 6, 1927 and the eve of the Reichstag election of March 5, 1933, Hitler had 455 public appearances, with a gross estimated attendance of at least 4.5 million. ${ }^{1}$ In only four years, the NSDAP evolved from

\footnotetext{
${ }^{1}$ We estimated attendance figures from available police reports and imputed missing values from press releases when necessary. For data sources, estimation procedures, and detailed descriptive statistics, see Appendix C.
} 
a radical fringe group, garnering less than three percent of the vote at the 1928 Reichstag election, into the most popular German party, with more than 37 percent of the national vote in July 1932, effectively paving the way for the Nazi takeover in March 1933.

\section{Introduction}

After observing the influence Hitler seemed to wield through the use of propaganda, refugee-scholar Paul Lazarsfeld fielded a panel survey in Erie County, Ohio during the run-up to the 1940 U.S. presidential election. This marked the beginning of modern research into campaign effects (Hillygus, 2010). The study's findings were surprisingthey did not substantiate Lazarsfeld's motivating concern that campaigns could arbitrarily manipulate the public. Instead, the presidential campaign was found to merely activate the voters' predispositions (Lazarsfeld, Berelson and Gaudet, 1948). Subsequent studies came to similar conclusions (Berelson, Lazarsfeld and McPhee, 1954; Campbell, Converse and Miller, 1960) and entrenched the minimal effects paradigm that would dominate mass communication research for decades (Klapper, 1960; Bennett and Iyengar, 2008). In a way, however, the bulk of early empirical work focused on a least likely case. As Iyengar and Simon $(2000,151)$ note, identifiable net effects should be limited to highly unbalanced campaigns in which one candidate has a clear resource or skills advantage-a condition that is rarely met in U.S. presidential campaigns (also see Gelman and King, 1993). Hitler's campaign, by contrast, far exceeded any of his rivals' efforts; the manipulative techniques employed were novel and sophisticated, and the use of modern technology, such as aircraft and loudspeakers, guaranteed Hitler an unparalleled geographic penetration and public attention (Paul, 1990). Tentative evidence for strong effects is indeed compelling: the numerous gag orders already speak volumes about the authorities' beliefs in Hitler's agitational potency, there were signs of electoral stagnation and organizational decay when the bans were in force, the unparalleled campaign activities that followed their repeal coincided with a steep electoral rise for the Nazi party, and plenty of reports from contemporary witnesses further corroborate the importance of Hitler's campaign for the Nazis' success (Abel, 1965).

Only a handful of studies have thus far attempted to systematically assess the effectiveness of early Nazi propaganda. ${ }^{2}$ Most recently, Adena and her colleagues (2015) measure local exposure to radio broadcasting using a method for predicting the spatial attenuation of radio signals. They find that exposure was negatively related to NSDAP support before the Nazi seizure of power and positively related soon afterwards as the party assumed control over the mass media. In line with this finding, the authors also provide evidence that radio content before 1933 was largely pro-government and against the Nazis.

${ }^{2}$ Voigtländer and Voth $(2014,2015)$ examine the effectiveness of Nazi propaganda under the dictatorship (the years 1933-1945) using novel data and empirical strategies. 
These results corroborate the portrayal of early Nazi propaganda by later broadcasting director and Goebbels' deputy Eugen Hadamovsky $(1933,44)$ :

"All the means of public opinion were denied to Hitler. His newspapers were banned, he was denied use of the radio, his brochures and leaflets were confiscated. He had no choice but to reach the masses directly through constantly growing mass rallies."

Ohr (1997) collects data on local party events in Hessian communities and finds that in the period between the 1930 national and the 1931 regional parliamentary elections, there is a positive relationship in the changes of municipal Nazi vote shares. Wernette (1974) also codes local Nazi election activities during the run-up to the 1930 Reichstag election from a national newspaper and finds a positive correlation with changes in municipal Nazi vote shares in the period 1928-1930. Ciolek-Kümper (1976) focuses on Hitler appearances and-roughly - compares changes in ward-level Nazi vote shares at the regional election in Lippe on January 15, 1933 relative to the preceding Reichstag election in November 1932. She finds no evidence of the effectiveness of Hitler's intense campaign efforts. Plöckinger (1999) looks at differences between local- and regional-level Nazi vote shares at the July and November 1932 Reichstag elections in Bavaria but does not find any deviations between municipalities visited by Hitler and those that were not. Though inventive, the latter studies are limited in their geographic and temporal scope. They also potentially suffer from causality issues which received much less attention at the time these studies were conducted than they do today.

In this study, we revisit the question of how effective early Nazi propaganda was in garnering electoral support in Weimar Germany. Our substantive focus is on Hitler's public speeches as the Nazis' chief campaign tool at that time. We rely on extensive original data that has superior geographic and temporal scope and resolution. We draw on the campaign resource allocation literature and use a semi-parametric difference-indifferences estimation strategy to account for often ignored endogeneity problems in the assessment of local campaign effects. In doing so, we also provide rare insight into the campaign strategy of the Nazi party. We discuss the limitations of our study and provide several robustness checks. Finally, we consider the implications of our findings for current research into campaign and leader effects.

\section{Estimating Campaign Effects: Problems and Strategies}

Campaign effects on voting behavior and election results are notoriously difficult to detect in a campaign realm characterized by the selective exposure of voters to a diffuse stream of countervailing campaign messages. Only since the late 1980s has the paradigmatic view of minimal campaign effects been challenged by scholars using novel data and 
sophisticated methodologies such as laboratory experiments (Iyengar and Kinder, 1987), rolling surveys (Johnston et al., 1992), field experiments (Gerber and Green, 2000), and natural experiments (Huber and Arceneaux, 2007).

While the historical perspective of our research precludes attractive design options that employ randomization or survey data, ${ }^{3}$ a number of recent studies try to gauge the impact of campaign stops on voting behavior by using widely available information about the candidates' campaign itineraries and local-level election results (Campbell, 2008; Herr, 2002; Hill, Rodriquez and Wooden, 2010; Holbrook, 2002; Jones, 1998; King and Morehouse, 2004; Sellers and Denton, 2006; Vavreck, Spiliotes and Fowler, 2002). Such studies typically struggle with identification issues that challenge causal claims. Like any observational study, they are subject to potential confounding (see Goldstein and Holleque, 2010). Confounding would occur, for instance, if candidates and their staff deliberately selected locations for their appearances where they expected a large pool of easy-to-mobilize supporters or anticipated a close race. If a researcher failed to properly take into account such confounders (e.g., latent support, marginality), she would probably overestimate the effect of appearances on the candidate vote share and voter turnout. ${ }^{4}$ We use a semi-parametric difference-in-differences estimation strategy to account for potential confounding due to observed and unobserved variables (see Abadie, 2005; Heckman, Ichimura and Todd, 1997). In doing so, we specify a parametric model to predict the probability of Hitler appearances in a geographic unit and match visited units with control units that feature a similar predicted probability before the differencein-differences analysis.

Beyond potential confounding, such studies of candidate appearances may be considered what epidemiologists call spatial ecological studies (Wakefield, 2004). Spatial ecological studies use geographic proximity to a presumed cause (in our case: campaign appearances) as a surrogate for individual exposure to the cause (attendance to the campaign event) and measure the response (voting behavior) at the level of geographic units (communities or counties). ${ }^{5}$ A number of additional biases may arise in such a design. It is well known that group-level observations can be highly misleading when aggregate

${ }^{3}$ See Collier (1944) for an early (non-randomized) experiment on the attitudinal effects of Nazi propaganda materials on a sample of U.S. college students in 1941-1942. Also see Reuband (2006), who uses a retrospective survey conducted in 1949 to assess mass support during the Nazi regime.

${ }^{4}$ In their original study, Shaw and Gimpel (2012) randomize a candidate's travel schedule during the 2006 Texas gubernatorial race in order to make campaign appearances statistically independent of other factors related to the outcome of interest. While such a randomized field experiment is a powerful design for valid causal inference, even the authors seem surprised that the candidate's staff actually agreed to let scholars interfere in their strategic planning (Shaw and Gimpel, 2012, 140). Moreover, this is an apparently infeasible approach for a retrospective study like ours.

${ }^{5}$ Shaw and Gimpel (2012) field a large-scale survey of registered voters that includes items on both exposure to the campaign events and candidate support. Such data would have allowed them to estimate causal effects of individual exposure by using an instrumental variable approach (see Angrist, Imbens and Rubin, 1996). However, Shaw and Gimpel (2012) limit their empirical analysis to before-after comparisons within and between geographic units. 
data are used to make inferences about individuals. Even under unconfoundedness (e.g., by random assignment of campaign appearances), we cannot unambiguously attribute higher turnout or voter support in visited localities to increased propensities among those who attended the campaign events to turn out and vote for the candidate. Such aggregate effects may also come about, for instance, in the fashion of an indirect two-step flow of communication (Katz and Lazarsfeld, 1955), in which opinion leaders who would turn out and support their candidate anyway (i.e., for whom the individual effect of attendance is essentially zero) attend the event and are then motivated to mobilize and persuade others within their personal networks (Rosenstone and Hansen, 1993). In our particular case, positive effects of Hitler's campaign visits on local Nazi vote shares might also have occurred indirectly through intimidation. As Childers and Weiss (1990) document, violence was an integral part of Nazi mobilization strategy at the end of the Weimar Republic. If Hitler's appearances were regularly accompanied by assaults on political opponents, increases in Nazi vote shares at the following election could have been the result of selective abstention by supporters of opponent parties. Either way, campaign effects on local-level election outcomes are, like other neighborhood effects, emergent properties of the social interaction of the residents (Oakes, 2004). Therefore, one has to be cautious not to interpret even internally valid aggregate estimates of the effect of campaign appearances on election results in terms of the impact of individual attendance on voting behavior.

Finally, spatial ecological studies potentially suffer from ambiguities in separating exposure from non-exposure units. Effects of campaign events need not be restricted to the areal units for which we observe the outcomes of interest. For instance, voters and opinion leaders from neighboring units may also attend the events and thereby carry individual and network effects back home. Likewise, the geographic range of news media that cover the events may well exceed the borders of the units of analysis. Such spatial spillovers would violate the non-interference assumption underlying most methods for causal inference. Non-interference is an essential aspect of the stable unit-treatment value assumption (SUTVA), which implies that a treatment applied to one unit does not affect the outcome of other units. This allows researchers to employ multiple units for estimating causal effects (Rubin, 1980). To illustrate the implications, imagine that Hitler's appearances actually had their intended effect on Nazi support in the visited county, but that this effect carried over to neighboring counties through travel activity, personal networks, or media coverage. If these neighboring counties served as controls when assessing the effect of Hitler's appearance on the NSDAP vote in the exposure county, the effect estimate would obviously be biased downward because the average overtime difference in outcomes among control units would not properly reflect the expected developments in the absence of the appearance. We, therefore, exclude neighboring areas from the pool of controls in order to account for possible spillovers. 


\section{The Targeting of Candidate Appearances}

In light of the potential confounding factors discussed above, the first step in assessing the impact of candidate appearances on election returns is to theorize how such visits are being targeted and in what way these factors relate to the outcome of interest (Althaus, Nardulli and Shaw, 2002). In doing so, we adopt an instrumental view and assume that campaign activities serve to maximize votes while accounting for mobilization costs (Bartels, 1985; Brams and Davis, 1974; Colantoni, Levesque and Ordeshook, 1975; Cox, 1999). Candidates should focus their scarce resources accordingly-that is, on locations they expect personal appearances to favorably translate into additional votes, and specifically where additional votes would be decisive for winning mandates. The former suggests that rational campaigners primarily target locales with large numbers of eligibles and a high expected share of supportive voters. The latter expectation implies that candidates are more likely to visit competitive districts in which small vote shifts could change the allocation of mandates in their favor or to their detriment. All these factors-the number of eligibles, expected electoral support, and a party's expected competitiveness-are potential confounders in so much as they may also influence the outcome of interest. Applied to the present case, the size of the local electorate may be negatively linked to Nazi vote shares since rural areas were less populous and, at the same time, on average more supportive of the NSDAP than urban areas for programmatic reasons (Heberle, 1978; Thurner, Klima and Küchenhoff, 2015). Likewise, the classical decision-theoretic model of voting suggests that a party's expected competitiveness may directly affect the relative strength of parties through selective participation and strategic voting (Cox, 1999).

Local infrastructure is also relevant to mobilization costs. In the context of U.S. presidential campaigns, Holbrook's (2002) study of Truman's 1948 whistle-stop campaign and Althaus, Nardulli and Shaw's (2002) narratives of the boat trips down the Mississippi river by $\mathrm{Al}$ Gore in 2000 and by Georg H.W. Bush in 1988 provide good examples of campaigns in which ground transportation connectivity mattered. A remarkable feature of Hitler's 1932 campaign was that, for the first time in history, he chartered a plane to transport him to certain campaign events. Under the ambiguous label "Hitler over Germany", he made nearly 150 appearances from April until November 1932. Therefore, distance to the nearest airfield should have mattered for targeting event locations starting with the 1932 elections. The strength of local party organizations is often quoted as an important source of logistic support and secondary mobilization (Cox, 1999; Rosenstone and Hansen, 1993). Some authors even consider local organizational strength as another campaign tool subject to strategic allocation (Bartels, 1985), which reminds us that a leading candidate's campaign is not a unitary entity but rather a set of efforts undertaken by various agents. For instance, Kelley (1961) found in his study of U.S. presidential campaigns that contenders used their running mates' schedules in either complementary or duplicative ways. Geographically or temporally complementary campaign schedules carry the risk of offsetting campaign effects (Finkel, 1993), while duplicative itineraries bring about potential misattribution of campaign effects. One way or the other, we need 
to account for the activities of other Nazi speakers when assessing the effects of Hitler's public appearances. The following section introduces measurements for all relevant confounders.

\section{Data Collection and Measurement}

Period of observation. Our empirical analysis covers the period between the repeal of the speaking ban on Hitler in Bavaria on March 6, 1927 and the last (halfway) competitive Reichstag election on March 5, $1933 .{ }^{6}$ Five national parliamentary elections (on May 20, 1928, September 14, 1930, July 31, 1932, November 6, 1932, and March 5, 1933) and a two-round presidential election (on March 13, 1932 and April 10, 1932) were held within this period. Our difference-in-differences approach focuses on changes between the four consecutive parliamentary elections and both rounds of the presidential election, respectively.

Areal units. The availability of election statistics dictates our choice of areal units. Thanks to a data collection effort of epic proportions by Jürgen Falter and collaborators (Falter and Hänisch, 1990), digitalized community-level election statistics are available for the 1928, 1930, and 1933 elections; however, they are not available for the elections in 1932, whose results the Reich Statistical Office (Statistisches Reichsamt) reported only for the higher administrative levels of counties (Kreise) and county boroughs (kreisfreie Städte) (see Hänisch, 1989, 45). This leaves us with a single election pair (1928-1930) for a community-level difference-in-differences analysis. We will use the community-level data $(N=3,864)$, among other things, to check the sensitivity of our empirical results for potential violations of the non-interference assumption discussed above. Other than this, our analytical focus will be on the counties and county boroughs $(N=1,000)$. While election statistics are available at the county and, partly, the municipal level, neither level was relevant for the apportionment of parliamentary seats. Mandates were allocated at the level of the 35 primary districts (Wahlkreise) and 16 secondary districts (Wahlkreisverbände), which will serve as additional geographical layers to compute measures of the NSDAP's competitiveness.

Areal units are key in generating and combining substantive variables. Unfortunately, the Falter data do not readily contain the geographic information necessary to do so. ${ }^{7}$ In an independent data collection effort, we retrieve the center coordinates of the municipalities and county boroughs included in Falter and Hänisch (1990) from the

${ }^{6}$ Gag orders in other regions were remitted successively: Saxony on January 26, 1927, Hamburg on March 23, 1927, Baden on April 22, 1927, Lübeck on May 18, 1927, and both Anhalt and Prussia on November 16, 1928 (Bruppacher, 2012, 181-198).

${ }^{7} \mathrm{O}^{\prime}$ Loughlin and colleagues (O'Loughlin, Flint and Anselin, 1994; O'Loughlin and Shin, 1995) digitalize county boundaries for the 1930 Reichstag election based on U.S. military maps from World War II. However, this map does not contain geographic information about most county boroughs and about none of the 
Google Maps API service (Google Inc., 2015). Whole counties are geo-referenced in terms of the center coordinates of their main towns or cities in order to account for the uneven population distribution within counties. Details and links to computer code can be found in Appendix A.

Outcome variables. The primary outcome of interest is the number of NSDAP votes in a Reichstag election in an areal unit relative to the voting-eligible electorate. The reason for standardizing against the number of eligible - not actual — voters is that the specific apportionment method used in Reichstag elections guaranteed each party one seat per 60,000 votes (see Appendix E). Therefore, an increase in the number of votes from one election to the next would increase a party's chances of winning additional seats irrespective of the vote gains and losses for other parties. We also use the vote share of the communist party (Kommunistische Partei Deutschlands, KPD) as the Nazi's major adversary and the turnout rate as alternative outcomes. For the 1932 presidential elections, we use vote shares for Adolf Hitler and Ernst Thälmann, the KPD's candidate, as outcomes of interest. The relative size of the areal units' voting-eligible population serves as a weighting variable in the difference-in-differences analysis. Given its vast variability across units-county-level electoral populations range between 184 and 871,764, with a mean of 41,358 eligiblesappropriate weights are imperative for our analysis (Ridgeway et al., 2015). All election data are taken from Falter and Hänisch (1990).

Exposure. Our main source of information about Hitler's public appearances is the multivolume edition "Hitler. Reden, Schriften, Anordnungen" (Hitler. Speeches, Writings, Directives) by the Institute for Contemporary History Munich (Hitler, 1992, 1994a,b,c, $1995,1996,1997,1998)$. For each appearance within the specified period, we hand-code its date, location, type of event (public or private) and, if available, attendance figures by source (police reports, press coverage, Nazi press coverage). As the edition only covers the period until Hitler's appointment as head of the national government on January 301933 , we consult Bruppacher (2012) to fill the gap until the Reichstag election on March 5, 1933. For validation we use Bruppacher (2012) and Domarus (1973) and retrieve information from hitlerpages.com, a website maintained by a Dutch amateur historian that provides a daily account of Adolf Hitler's life compiled from various sources. In sum, we are able to identify 566 Hitler appearances in the specified period, 455 of which were public. ${ }^{8}$ Figure 1 provides a timeline of events for the entire observation period. ${ }^{9}$ Apparently, Hitler's campaign activities had already been intense in the period between the 1928 and

communities. The former would lead to the exclusion of a substantial share of the voting eligible population from the analysis. The latter would prevent us from disaggregating our study to the municipality level. Paul Thurner and his colleagues (2015) made a fresh geo-coding effort including all the counties and county boroughs. For the last-mentioned reason, however, we do not use their materials either.

${ }^{8}$ Most of the events we classified as non-public were speeches on the occasion of meetings with party officials.

${ }^{9} \mathrm{~A}$ detailed description of the coding procedure and additional figures can be found in Appendix B. 
Figure 1: Timeline of Hitler's public appearances, March 1927 to March 1933.

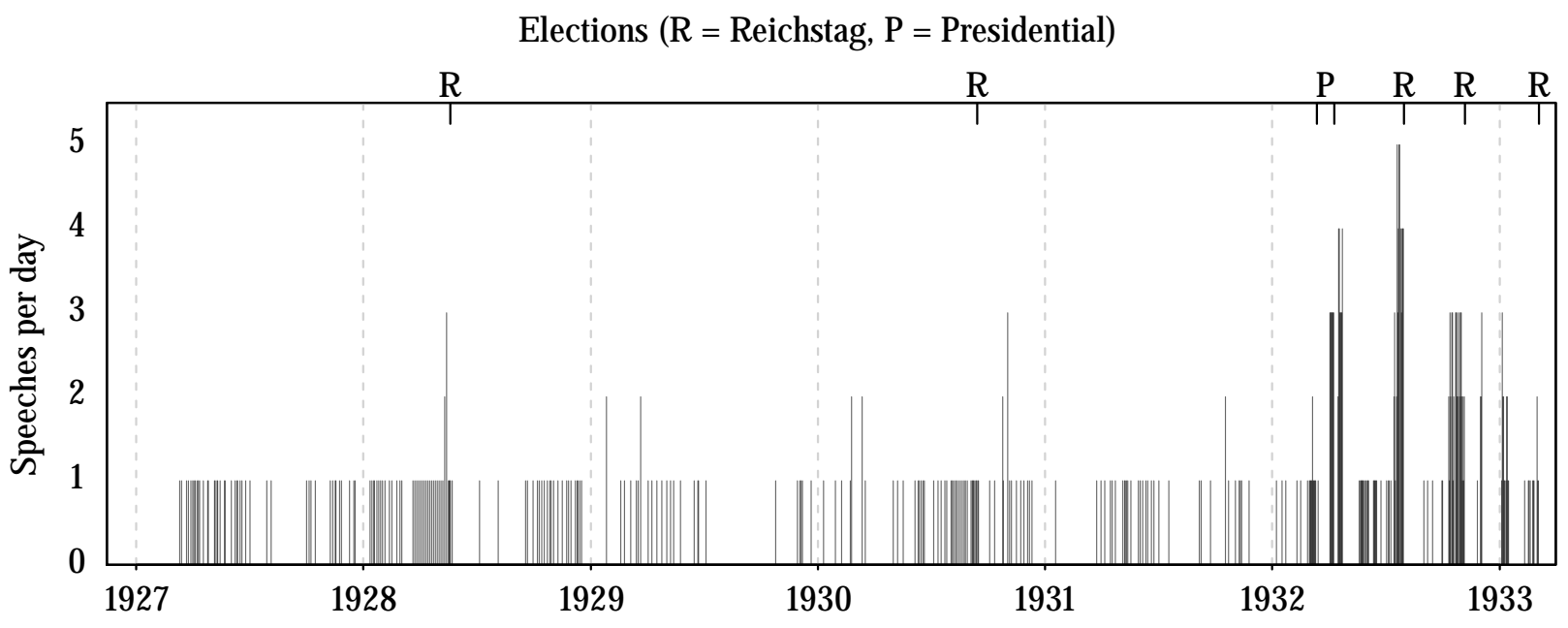

1930 elections (84 appearances) and culminated in the run-up to the 1932 presidential and Reichstag elections (243 appearances). In early 1933, as Hitler had already been appointed head of government, the NSDAP's strategy quickly switched from winning votes to repression (Evans, 2005). Of the meager 36 events recorded between November 7, 1932 and March 5, 1933, as many as 16 related to the January 15,1933 regional elections in Lippe. ${ }^{10}$

In order to assess the effect of Hitler's appearances on local election returns, we would ideally know whether or not (or rather: to what extent) the local population for which we observe the outcome had been exposed to the event. This information is simply not available. Like other spatial ecological studies, we use spatial proximity to the events as a surrogate for exposure. First, Hitler appearances are point-referenced according to their location (municipality or borough center, possibly even the specific venue) using the Google Maps API service. We then classify those counties and county boroughs (municipalities in the municipal-level analysis) whose center coordinates were situated within a radius of 10 kilometers from an event location at anytime during an inter-election period as exposure units. Alternative specifications of the exposure variable with varying geographical and temporal scope will be considered in the section on robustness.

Competitiveness. The rational actor perspective suggests that Hitler and the NSDAP focused their scarce campaign resources on close races-that is, on electoral districts where the stakes of winning additional seats and of losing seats won in previous elections were high. To measure the NSDAP's local electoral stakes, we follow lines similar to Grofman and Selb (2009) and develop party-specific competition indices that are sensitive to the nature of the automatic apportionment method used at that time (Schanbacher, 1982).

\footnotetext{
${ }^{10}$ See the clustering of events in Figure B1 in the Appendix.
} 
The indices are specified at the level of the primary and secondary electoral districts (Competitiveness 1 and 2, respectively). They reflect the minimum vote distance of the NSDAP to winning an additional seat or to losing their final seat at the respective level at the previous election relative to the highest possible vote distance to a seat gain or loss. An index value of 1 indicates maximum competitiveness, a value of 0 indicates the theoretical minimum. Details of the calculations and descriptive statistics are given in Appendix E.

Organizational strength. It has been argued that local infrastructure is relevant to mobilization costs and that the strength of local party organization is one important infrastructural factor. Apart from some regional studies (Anheier, 2003; Anheier, Neidhardt and Vortkamp, 1998), there is no systematic nationwide information about the local organizational strength of the NSDAP and its development over time. As a proxy for organizational strength, we estimate county-level party membership totals $($ in 1,000$)$ based on samples drawn from the two original NSDAP member files archived at the Berlin document Center by teams of researchers in Berlin (Falter and Kater, 1993) and Minneapolis (Brustein, 1998). The sample data include, inter alia, information about the place and date that the members joined. The thorough description of the sampling procedures in Schneider-Haase (1991) allow us to calculate appropriate design weights. Unfortunately, the researchers used fixed yearly quotas for entries in the period 1930-1933 so that it is impossible to calculate time-varying weights. Auxiliary information about the annual development of national membership figures from Kater (1980) is used to generate election-specific estimates. Details of the estimation procedure and descriptive statistics are given in Appendix F.

Distance to nearest airfield. Of particular importance for mobilization costs as of 1932 is the distance to the nearest airfield. We consult several Wikipedia entries and a privatelyrun website ${ }^{11}$ to identify a total of 70 civilian airfields in operation at that time. We use the Google Maps API service to geo-code the airfields, which provides the basis for calculating minimum distances to an airfield (in $100 \mathrm{~km}$ ) for each municipality, county borough, and county. Figure G1 in the Appendix maps the location of the airfields as well as the minimum distances.

Number of eligibles and previous vote share. Our theoretical considerations suggest that rational campaigners primarily target locales with large numbers of eligibles and a high expected share of supportive voters. Therefore, we include the number of eligibles (in 100,000) and the vote share of the NSDAP (for the 1932 presidential election: Hitler) at the previous election (i.e., the first election in each election pair considered). Information on both variables is taken from Falter and Hänisch (1990).

\footnotetext{
${ }^{11}$ http://www.forgottenairfields.com/.
} 
Goebbels' appearances. To account for the eventuality that Hitler's campaign schedule was complemented or duplicated by those of other high-profile Nazi speakers, we collect information about the public appearances of Joseph Goebbels, the second most important Nazi speaker after Hitler. We first conduct an automatic search of key words ${ }^{12}$ using a digital version of his diaries (Goebbels, 1992) and then manually code information on places, dates and types of speeches (public or private). Finally, we geo-code the appearances using the Google Maps API service. In total, we are able to collect data on 200 public speeches, an overwhelming majority of which (110) were held in Berlin. Figure B2 in the Appendix maps the locations of Goebbels' appearances.

Previous appearances. In addition to the matching variables listed, we include a binary variable that indicates whether Hitler previously (i.e., before the last election) visited a county in order to help control for unobserved confounders, assuming that those factors had already affected past targeting decisions. Election-specific summary statistics of all the variables and supplementary maps are given in Appendix $\mathrm{H}$.

\section{Predicting Hitler's Appearances}

In the first stage of our empirical analysis, we model the election-specific probability of a Hitler visit to a community or county as a function of the above covariates. Predictions from these models will then be used in the causal inference step to trim the sample in order to include as controls only those counties and communities which are similar to exposure units in terms of their estimated propensity score (while also being geographically distant enough from exposure units). The results from the propensity score estimation are interesting in their own right, too, since they provide rare systematic insight into early Nazi campaign strategy. While there are numerous studies on the organization of Nazi propaganda (e.g. Anheier, 2003; Rösch, 2002) and the manipulative techniques employed (e.g. Anheier, Neidhardt and Vortkamp, 1998; Paul, 1990), little is known about the targeting of candidate appearances.

Table 1 reports probit estimates and their standard errors (clustered by primary electoral district) for each election separately. As one would expect, the size of the eligible voting population in a county turns out to be a consistent predictor of Hitler's campaign appearances across elections. Also in line with our expectations, the distance to the nearest airfield is a significant predictor of Hitler visits as of the 1932 elections-Hitler's first campaign trip by plane did not occur before before April 3, 1932 (Bruppacher, 2012, 265). The exceptionally large coefficient on airfield distance referring to the 1933 election is due to the extraordinarily intense regional election in Lippe in January 1933 and its proximity to the airports of Bielefeld and Hannover-Vahrenwald (see Figure H2 in the Appendix). The

\footnotetext{
${ }^{12}$ The list of key words includes (root) words related to speeches and rallies: "sprech", "gesprochen", "rede", "kundgebung", "ansprache", "veranstaltung", "vortrag".
} 
Table 1: Probit estimates of Hitler appearances by election. Standard errors in parentheses.

\begin{tabular}{|c|c|c|c|c|c|c|}
\hline & Sep 1930 & $\begin{array}{c}\text { Sep } 1930 \\
\text { (mun.) }\end{array}$ & Apr $1932(\mathrm{P})$ & Jul 1932 & Nov 1932 & Mar 1933 \\
\hline Competitiveness 1 & $\begin{array}{c}0.311 \\
(0.291)\end{array}$ & $\begin{array}{c}0.737^{* * *} \\
(0.153)\end{array}$ & & $\begin{array}{c}-0.653^{*} \\
(0.386)\end{array}$ & $\begin{array}{l}-0.294 \\
(0.424)\end{array}$ & $\begin{array}{l}1.251^{*} \\
(0.748)\end{array}$ \\
\hline Competitiveness 2 & $\begin{array}{c}0.668^{* * *} \\
(0.226)\end{array}$ & $\begin{array}{c}0.770^{* * *} \\
(0.125)\end{array}$ & & $\begin{array}{l}0.333^{*} \\
(0.179)\end{array}$ & $\begin{array}{l}-0.256 \\
(0.209)\end{array}$ & $\begin{array}{c}0.094 \\
(0.310)\end{array}$ \\
\hline Organizational strength & $\begin{array}{l}-0.704 \\
(0.513)\end{array}$ & $\begin{array}{c}-0.616^{* * *} \\
(0.239)\end{array}$ & $\begin{array}{l}-0.166 \\
(0.260)\end{array}$ & $\begin{array}{l}-0.106 \\
(0.190)\end{array}$ & $\begin{array}{c}-0.257^{*} \\
(0.155)\end{array}$ & $\begin{array}{l}-0.240 \\
(0.173)\end{array}$ \\
\hline Distance to nearest airfield & $\begin{array}{l}-0.323 \\
(0.282)\end{array}$ & $\begin{array}{c}0.050 \\
(0.164)\end{array}$ & $\begin{array}{c}-1.943^{* * *} \\
(0.612)\end{array}$ & $\begin{array}{c}-0.334^{*} \\
(0.190)\end{array}$ & $\begin{array}{l}-0.367 \\
(0.235)\end{array}$ & $\begin{array}{c}-3.574^{* * *} \\
(0.780)\end{array}$ \\
\hline Number of eligibles & $\begin{array}{c}0.695^{* * *} \\
(0.164)\end{array}$ & $\begin{array}{c}0.736^{* * *} \\
(0.103)\end{array}$ & $\begin{array}{c}0.196 \\
(0.216)\end{array}$ & $\begin{array}{c}1.200^{* * *} \\
(0.270)\end{array}$ & $\begin{array}{c}0.593^{* * *} \\
(0.214)\end{array}$ & $\begin{array}{c}0.577^{* *} \\
(0.240)\end{array}$ \\
\hline Previous NSDAP vote share & $\begin{array}{l}3.394 \\
(2.146)\end{array}$ & $\begin{array}{l}2.135^{* *} \\
(0.945)\end{array}$ & & $\begin{array}{c}0.579 \\
(0.847)\end{array}$ & $\begin{array}{l}0.989^{*} \\
(0.589)\end{array}$ & $\begin{array}{c}0.158 \\
(1.088)\end{array}$ \\
\hline Previous Hitler vote share & & & $\begin{array}{c}-5.544^{* *} \\
(1.823)\end{array}$ & & & \\
\hline Previous appearance & $\begin{array}{c}0.844^{* * *} \\
(0.185)\end{array}$ & $\begin{array}{c}0.886^{* * *} \\
(0.086)\end{array}$ & $\begin{array}{c}5.719 \\
(240.510)\end{array}$ & $\begin{array}{c}0.985^{* * *} \\
(0.129)\end{array}$ & $\begin{array}{c}0.967^{* * *} \\
(0.129)\end{array}$ & $\begin{array}{c}0.418^{* *} \\
(0.199)\end{array}$ \\
\hline $\begin{array}{l}\text { Goebbels appearance } \\
\text { (Intercept) }\end{array}$ & $\begin{array}{c}1.077^{* * *} \\
(0.200) \\
-2.269^{* * *} \\
(0.249)\end{array}$ & $\begin{array}{c}1.189^{* * *} \\
(0.112) \\
-2.715^{* * *} \\
(0.140)\end{array}$ & $\begin{array}{c}7.513 \\
(6,609.109) \\
-4.750 \\
(240.510) \\
\end{array}$ & $\begin{array}{c}0.708^{* * *} \\
(0.207) \\
-1.161^{* * *} \\
(0.328)\end{array}$ & $\begin{array}{c}1.165^{* * *} \\
(0.381) \\
-1.714^{* * *} \\
(0.425) \\
\end{array}$ & $\begin{array}{c}1.618^{* * *} \\
(0.293) \\
-2.337^{* * *} \\
(0.750)\end{array}$ \\
\hline Mc-Fadden's Pseudo R2 & 0.31 & 0.27 & 0.51 & 0.24 & 0.23 & 0.44 \\
\hline Observations & 1,000 & 3,864 & 685 & 1,000 & 953 & 953 \\
\hline Log Likelihood & -229.763 & -712.633 & -63.317 & -398.459 & -252.176 & -118.828 \\
\hline Akaike Inf. Crit. & 477.526 & $1,443.267$ & 140.633 & 814.918 & 522.353 & 255.655 \\
\hline
\end{tabular}

campaign trail also tended to stop where the NSDAP did well in the previous electionalthough the coefficients are, at most, weakly significant—and where the last election was close from the party's viewpoint. The parameter estimates indicate a negative relationship between the strength of local party organizations and the probability of a visit. An ad hoc interpretation of this finding would be that Hitler appearances were targeted at areas lagging behind in terms of organizational development in order to increase party membership. Bytwerk $(1981,16)$ argues that Hitler appearances served to boost local NSDAP membership. Unfortunately, the available samples from the NSDAP member files are too small to detect local changes in membership in the immediate aftermath of Hitler appearances. What additional analyses show, however, is that local organizational development in the whole legislative period following an election did not systematically differ between exposure and non-exposure units. ${ }^{13}$. The significantly positive coefficient associated with Goebbels' appearances suggests that Goebbels' campaign schedule tended to duplicate Hitler's. Thus, if we ignored Goebbels' activities, there would be a risk in

\footnotetext{
${ }^{13}$ See Table I39 in the Appendix.
} 
the subsequent analyses of erroneously ascribing campaign effects to Hitler, whereas they actually trace back to Goebbels. Finally, previous campaign appearances prove to be useful predictors of current events, indicating that there are factors relevant to (past and current) targeting choices that are not appropriately taken into account in our model specification. ${ }^{14}$ Nevertheless, the models fit the data remarkably well. Pseudo $\mathrm{R}^{2}$ values range between 0.23 in November 1932 and 0.51 in April 1932. That is, Hitler's campaign schedule appears to be pretty much in accord with an instrumental account of campaign resource allocation. Further, there does not seem to be much variation in campaign strategy over time.

\section{Matching and Covariate Balance}

There are a variety of matching methods available. The decision of which to choose from among them involves balancing the trade-offs inherent in each between variance and bias (Caliendo and Kopeinig, 2008). Our preferred method is 1:1 nearest neighbor matching without replacement subject to a caliper constraint of 0.25 standard deviations on the estimated propensity score. As an additional restriction, we drew no-matching areas of 10 kilometers around the exposure units and only matched control units outside these areas to safeguard our analysis against potential spillover effects. The definitions of exposure, no-matching, and potential control areas are illustrated in Figure 2. The matching results are illustrated in Figure 3. On one hand, the method throws away a nontrivial amount of information from both the pool of potential controls and the exposure group which may result in loss of statistical efficiency. On the other hand, expanding the caliper and/or oversampling controls for efficiency gains may increase bias in matching estimators due to the inclusion of poorer matches. ${ }^{15}$

Tables 2 and 3 report mean differences in variables between exposure and control units before and after matching plus a statistic that indicates the relative improvement of covariate balance through matching. Matching markedly improved covariate balance to the extent that there are barely any mean differences left. The seemingly curious instances of covariate balance deteriorating after matching occur in situations in which the distribution of variables was well balanced before matching. In these cases, slight distributional changes had massive consequences for the-relative-improvement statistic. Overall, the balancing statistics suggest that we can approach the causal analysis step with a certain measure of confidence, at least with regards to the observed potential confounders.

${ }^{14}$ The inflated SEs for "Previous appearances" and the intercept in the presidential election model are due to the fact that all 21 appearances (32 units affected using a $10 \mathrm{~km}$ radius) took place in counties that had been exposed to earlier appearances. For this election, an earlier visit was-empirically speaking-a necessary but not sufficient condition for an appearance.

${ }^{15}$ Figures I2, I3, and I4 in the Appendix report results for 1:5, 1:10 and 1:20 nearest neighbor matching. As expected, these matching estimators are (slightly) more efficient than those based on our preferred method, yet most of the estimates do not differ substantively. If they do, they tend to be smaller in magnitude, which we interpret as increased bias due to the inclusion of poorer matches. 
Figure 2: Illustration of radius definitions of exposure areas (dark grey; event locations in white), no-matching areas (light grey), and potential control areas (white; potential control units in black). Triangles represent centers of county boroughs. Dots represent municipal centers.

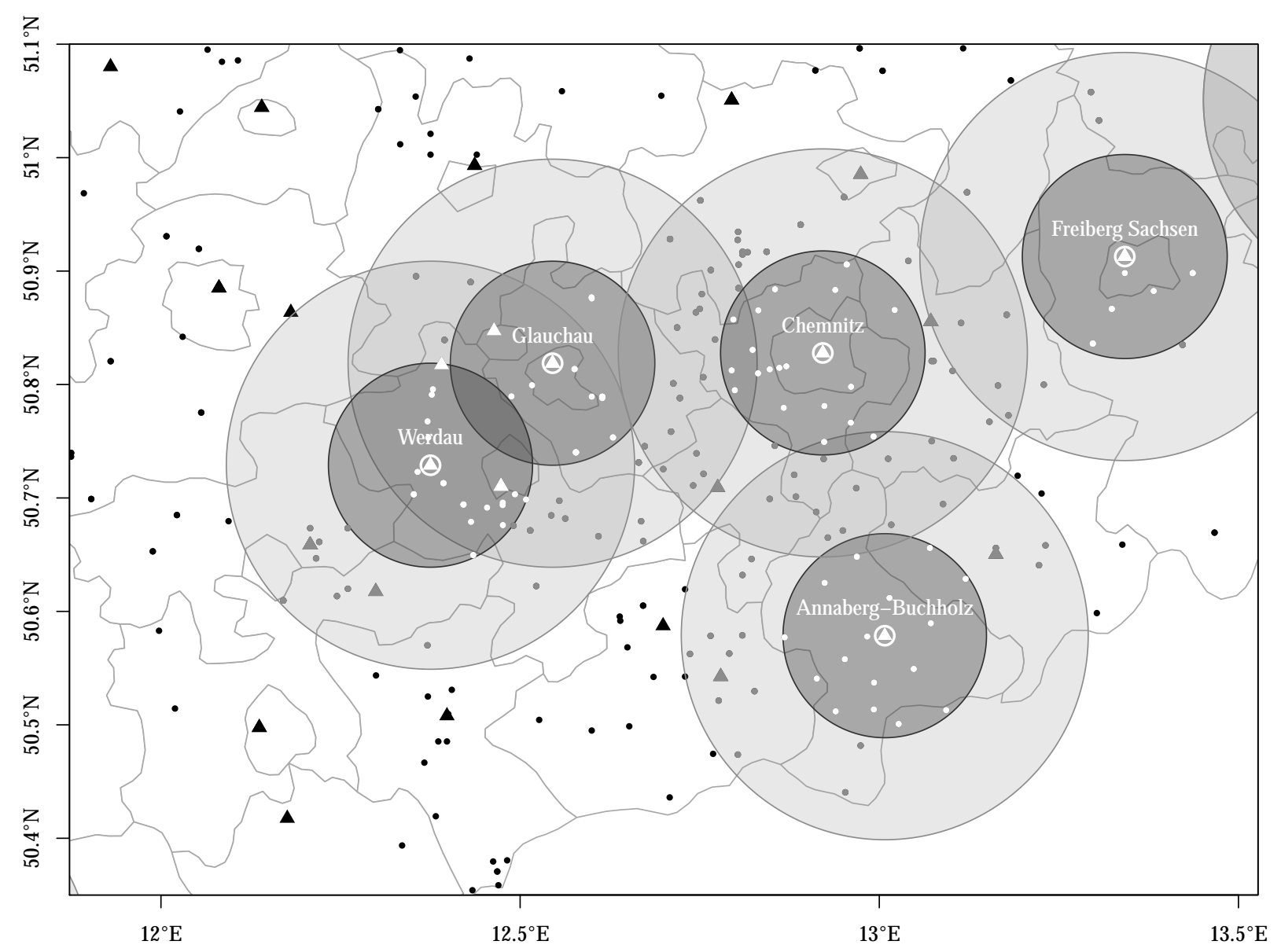

\section{Estimating Campaign Effects: Empirical Results}

The semi-parametric difference-in-differences estimate of the effect of Hitler appearances is the mean difference in the overtime changes of outcomes between the matched exposure and control units, with each unit weighted according to the size of its electoral population. Difference-in-differences estimation critically rests on the assumption that observed overtime changes in the control group reflect, on average, unobserved changes in the exposure group in the absence of treatment. A common plausibility check of such parallel trends is to compare pre-treatment changes over time between exposure and control units. Figure I1 in the Appendix does not indicate any differences in pre-treatment developments 
Figure 3: Predicted propensity scores by exposure and matching status. Lines indicate matched pairs.
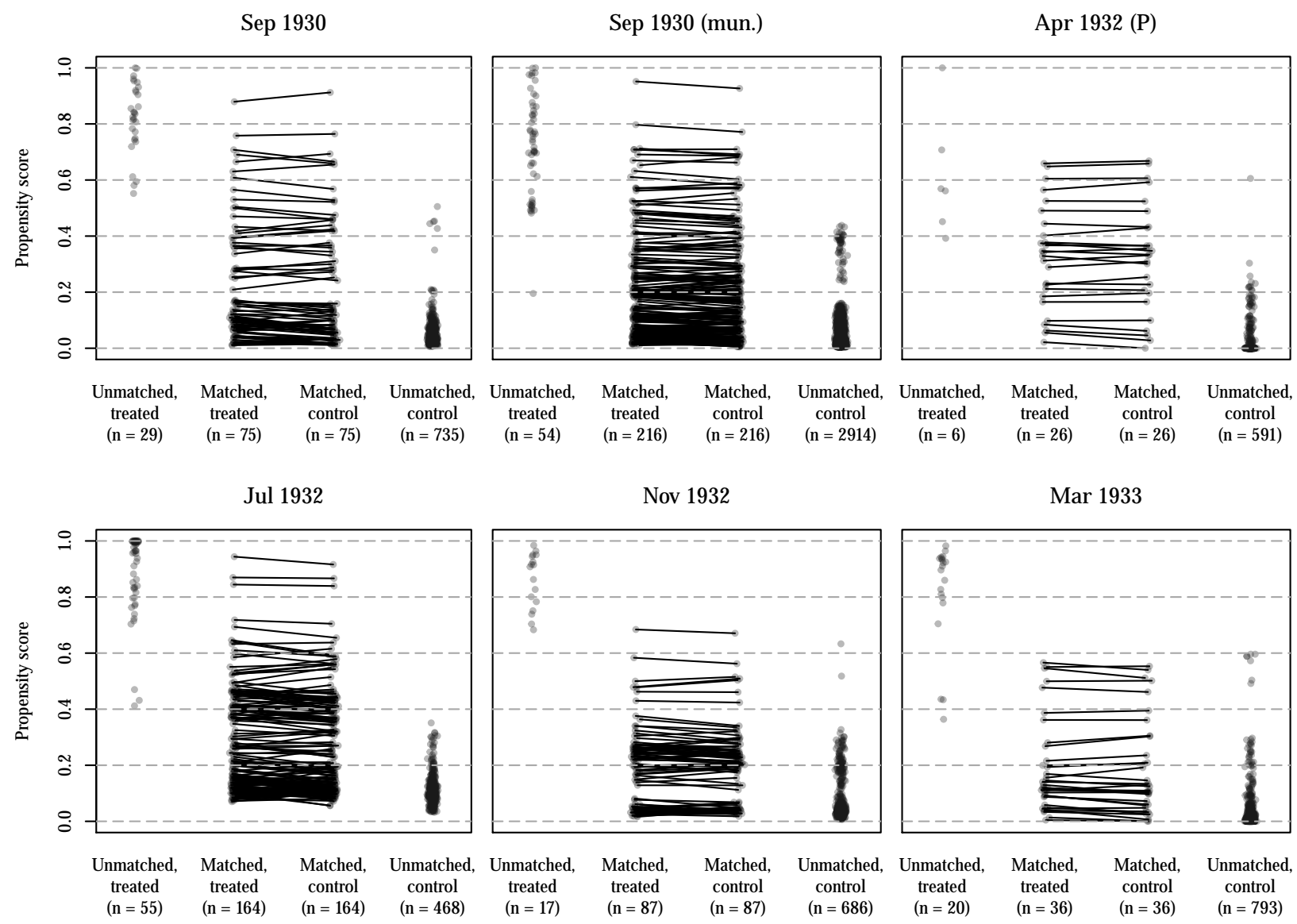

Table 2: Propensity score and covariate balance before and after matching. Mean differences on variables reported.

\begin{tabular}{|c|c|c|c|c|c|c|c|c|c|}
\hline \multirow[b]{2}{*}{ Variable names } & \multicolumn{3}{|c|}{ Sep 1930} & \multicolumn{3}{|c|}{ Sep 1930 (mun.) } & \multicolumn{3}{|c|}{ Apr $1932(\mathrm{P})$} \\
\hline & Before & After & \% Impr. & Before & After & \% Impr. & Before & After & \% Impr. \\
\hline Propensity score & 0.32 & 0.01 & 97 & 0.24 & 0.01 & 97 & 0.35 & 0.00 & 100 \\
\hline Competitiveness 1 & 0.05 & 0.05 & -8 & 0.10 & 0.05 & 48 & & & \\
\hline Competitiveness 2 & 0.16 & 0.09 & 44 & 0.16 & 0.03 & 84 & & & \\
\hline Organizational strength & 0.18 & -0.02 & 90 & 0.09 & 0.01 & 92 & 0.40 & 0.14 & 66 \\
\hline Distance to nearest airfield & -0.22 & -0.09 & 59 & -0.14 & -0.03 & 77 & -0.28 & -0.03 & 90 \\
\hline Number of eligibles & 0.78 & -0.06 & 93 & 0.33 & -0.01 & 98 & 0.85 & 0.26 & 69 \\
\hline Previous NSDAP vote share & 0.01 & 0.00 & 78 & 0.01 & 0.00 & 75 & -0.06 & 0.02 & 75 \\
\hline Previous appearance & 0.27 & -0.05 & 80 & 0.36 & 0.04 & 89 & 0.79 & 0.04 & 95 \\
\hline Goebbels appearance & 0.41 & 0.03 & 93 & 0.34 & -0.01 & 97 & 0.03 & 0.00 & 100 \\
\hline
\end{tabular}


Table 3: Propensity score and covariate balance before and after matching, continued. Mean differences on variables reported.

\begin{tabular}{|c|c|c|c|c|c|c|c|c|c|}
\hline \multirow[b]{2}{*}{ Variable names } & \multicolumn{3}{|c|}{ July 1932} & \multicolumn{3}{|c|}{ November 1932} & \multicolumn{3}{|c|}{ Mar 1933} \\
\hline & Before & After & \% Impr. & Before & After & \% Impr. & Before & After & \% Impr. \\
\hline Propensity score & 0.28 & 0.01 & 96 & 0.23 & 0.00 & 99 & 0.37 & 0.01 & 98 \\
\hline Competitiveness 1 & -0.02 & 0.00 & 94 & 0.00 & 0.03 & -5479 & -0.01 & 0.00 & 42 \\
\hline Competitiveness 2 & 0.03 & -0.02 & 21 & 0.00 & 0.01 & -248 & 0.02 & -0.06 & -234 \\
\hline Organizational strength & 0.54 & 0.04 & 93 & 0.60 & 0.04 & 93 & 0.93 & -0.11 & 88 \\
\hline Distance to nearest airfield & -0.16 & -0.05 & 70 & -0.19 & -0.01 & 96 & -0.32 & -0.02 & 93 \\
\hline Number of eligibles & 0.55 & 0.06 & 90 & 0.66 & 0.01 & 99 & 1.09 & -0.14 & 87 \\
\hline Previous NSDAP vote share & 0.00 & 0.00 & 92 & 0.00 & 0.01 & -135 & -0.03 & 0.01 & 76 \\
\hline Previous appearance & 0.36 & -0.05 & 85 & 0.51 & -0.01 & 98 & 0.49 & 0.14 & 72 \\
\hline Goebbels appearance & 0.20 & 0.04 & 82 & 0.13 & 0.01 & 91 & 0.36 & 0.03 & 92 \\
\hline
\end{tabular}

for the 1932 and 1933 Reichstag elections. ${ }^{16}$ Figure 4 reports difference-in-differences estimates for the five election pairs and their $80 \%$ and $95 \%$ confidence intervals, both for the matched and unmatched samples. The calculation of confidence intervals is based on robust standard errors to account for the clustering of temporal observations (preand post-exposure) within areal units. Results for three outcomes are reported: NSDAP (Hitler) vote shares, KPD (Thälmann) vote shares, and turnout. Most point estimates are in the range of $\pm 1 \%$ of the voting-eligible population, and hardly any coefficient is significantly different from zero at conventional probability levels. The strongest effect of $-2.4 \%$ pertains to electoral turnout in the 1928-1930 election pair, indicating that Hitler's early appearances had, on average, a demobilizing effect in exposure areas. A look at the other outcomes suggests that this demobilizing effect tended to harm the KPD but left the Nazi (population) vote share unaffected. This result supports Childers and Weiss' (1990) observation that a concomitant feature of Nazi campaign events was concerted violence to intimidate political opponents and their supporters. This specific empirical pattern disappears in later elections, perhaps indicating that Goebbels' attempt to align the paramilitary branch of the NSDAP (Sturmabteilung, SA) to the quasi-legal course adopted earlier was, at least in part, successful. Although estimated exposure effects on NSDAP vote shares are mostly zero, a negative effect occurs with the 1930-32 election pair-just when the Nazis took their greatest leap forward electorally!

The 1932 presidential runoff election deserves special mention. Incumbent president Hindenburg had emerged as the clear front-runner from the first election round on March 13, 1932, garnering $49.5 \%$ of the vote. By comparison, Hitler won $30.1 \%$ of the vote, and communist leader Ernst Thälmann secured 13.5\%. All other candidates combined received less than $7 \% 17$ and did not stand again in the decisive second round. Hindenburg, who did not bother to enter the electoral fray himself (Pyta, 2007, 475), issued an emergency decree that limited the campaign period preceding the runoff on April 10 to just the six

${ }^{16}$ Analogous tests are not available for the 1930 Reichstag and the 1932 presidential election since the NSDAP (Hitler) did not run in the reference elections of 1924 and 1925.

17The Social Democrats and the catholic Center Party did not nominate separate candidates. Rather, they supported Hindenburg in order to prevent the election of Adolf Hitler. 
Figure 4: Difference-in-differences estimates of exposure effects on NSDAP (Hitler) vote shares, KPD (Thälmann) vote shares, and turnout in national parliamentary and presidential elections 1930-33. Lines represent $80 \%$ and $95 \%$ confidence bands. Estimates are reported for unmatched and matched samples. For full model statistics, see Tables I1 to I3 in the Appendix.

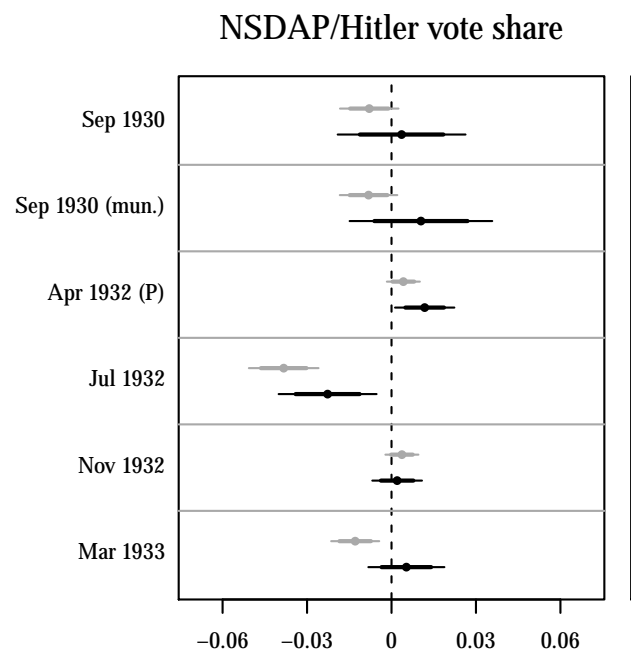

KPD/Thälmann vote share

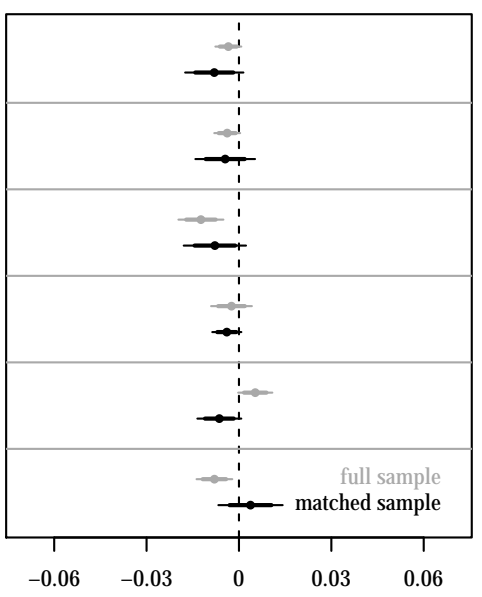

Turnout

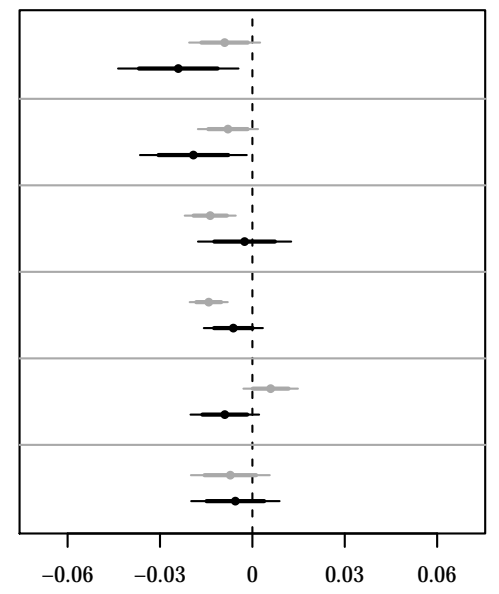

days prior to the election-a decision that prompted Hitler to utilize the airplane for the first time as a means of transportation for campaigning. The novel mode of transportation afforded him 21 campaign appearances spread over the whole country during this short period, with a maximum of 5 appearances per day. Even though Hitler eventually lost the election to Hindenburg, he still gained more than two million additional votes from the first to the second round. Our analysis suggests that some of the vote gains actually came from his campaign appearances. The finding that an unusually short and intense campaign had significant effects is in line with results from previous research which indicates that campaign effects run out quickly over time (e.g., Watt, Mazza and Snyder, 1993)-for example, due to the interference of offsetting campaign messages. In order to more systematically account for potential effect decay, we replicated our analysis, but this time only considering campaign appearances that took place within 2, 4, 8 and 12 weeks before an election. The results are, however, inconclusive. The details are reported in Tables I7 to I21 in the Appendix.

A final methodological remark, the matching approach obviously makes a difference. Difference-in-differences estimates of exposure effects on Nazi vote shares are consistently more negative when applied to the unmatched samples. This indicates that Hitler's campaign trail usually stopped where smaller increases (or larger decreases) in NSDAP vote shares were to be expected. One interpretation of this result would be that, for infrastructural reasons, Hitler's appearances were scheduled in more populous urban areas 
where the NSDAP tended to fare worse electorally for social structural and programmatic reasons (Heberle, 1978; Thurner, Klima and Küchenhoff, 2015).

\section{Robustness}

Absence of evidence is no evidence of absence. In this section, we will play devil's advocate and ask if there are reasons to suspect that actual campaign effects went undetected with our data and research design. The discussion is organized around three potential problems: SUTVA violations due to spatial spillovers and multiple versions of exposure, violation of the causal transience assumption with respect to previous Hitler appearances, and the limitations of our data and inferential approach to identify the effects of dynamic campaign strategies.

\section{Spatial Spillovers and Multiple Versions of Exposure}

One serious drawback of our study is the non-availability of exposure data. Like other spatial ecological studies, we have to make do with spatial proximity to events as a surrogate for exposure. Thus far, the specification of the exposure variable has arbitrarily fixed the geographic reach of Hitler appearances to a radius of 10 kilometers around venues. If the actual reach of events was wider than that, campaign effects might have spilled over to neighboring areas which served as potential comparison units in estimating (in this case, underestimating) effects (see Rubin, 1980). In the previous analysis, we drew nomatching zones around exposure areas to avoid this problem. As an alternative, we now vary the specifications of exposure areas from 5 to 50 kilometers around event locations for the 1928-1930 municipal-level data, which provide the highest spatial resolution. We likewise vary the range of the no-matching zones from 5 to 50 kilometers. The results plotted in Figure 5 indicate that initially positive effects of visits on NSDAP vote shares as well as initially negative effects on communist vote shares and turnout tend to fade out with increasing spatial distance. While these findings do not immediately suggest an optimal cutoff value for specifying exposure areas, our hunch is that a radius of $10 \mathrm{~km}$ plus an additional $10 \mathrm{~km}$ no-matching zone is a safe choice. The potential for even broader diffusion effects (e.g., through national media) seems limited given the limited access to public media; its mostly negative stance toward Hitler before 1933 (Adena et al., 2015); the low circulation figures of the Nazis' own national paper, Völkischer Beobachter (Layton, 1970); and the geographically fragmented press landscape at that time (Führer, 2008).

Apart from non-interference between units, SUTVA also requires that there be only a single version of treatment (Rubin, 1980). This assumption is unlikely to hold in the present case for at least two reasons. First, the number of Hitler appearances between elections differed between exposure counties and elections. While most of the exposure cases $(66 \%)$ actually reflect single campaign visits, there are other instances in which Hitler 
Figure 5: Difference-in-differences estimates of exposure effects on alternative outcomes at the 1930 national parliamentary election (municipality-level data). Specifications of exposure areas vary from 5 to $50 \mathrm{~km}$ around venues. Lines represent $80 \%$ and $95 \%$ confidence bands. Estimates are reported for unmatched and matched samples. For full model statistics, see Tables I4 to I6 in the Appendix.
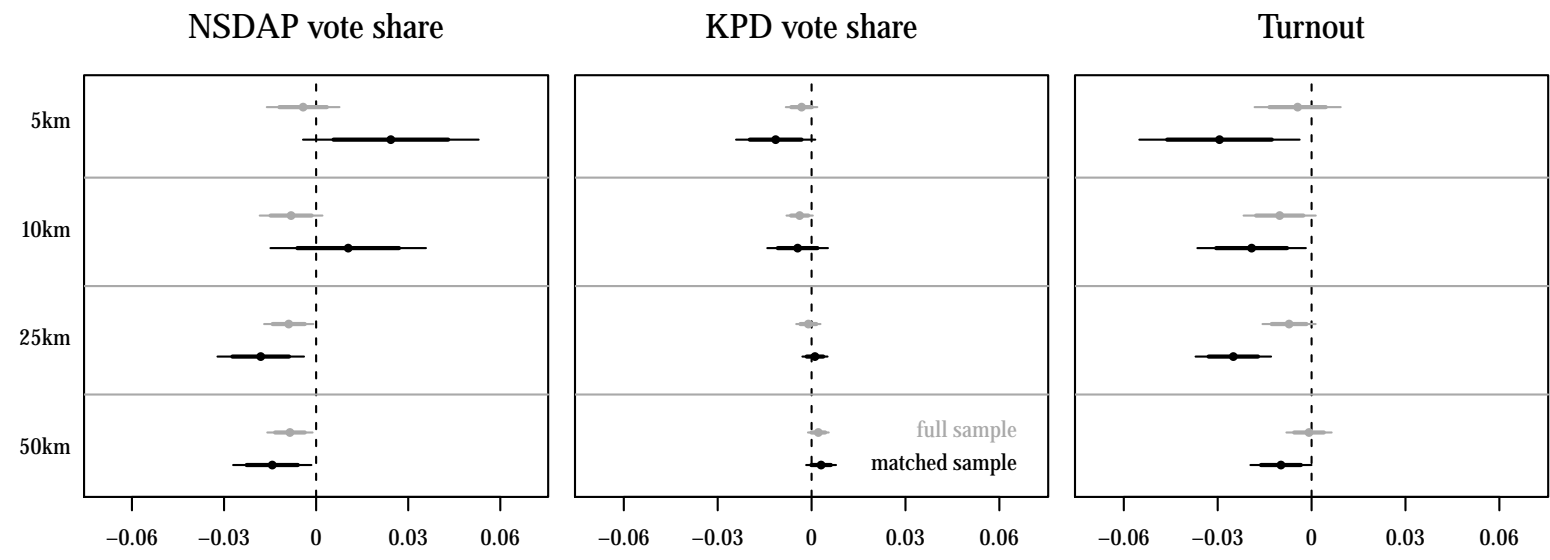

made multiple appearances in the run-up to an election. To name just the most extreme cases, Hitler held 17 public speeches between the July and November Reichstag elections of 1932 in Berlin-Mitte; for Munich, the home town of the Nazi movement, this figure was 37! To account for varying numbers of campaign events, we have replicated our matched difference-in-differences analysis for each of three exposure levels (see Imbens, 2000): one, two, and three or more campaign appearances. ${ }^{18}$ The results, which are detailed in Table I22 in the Appendix, do not point to any systematic differences between exposure levels. Second, the size of events also varied widely. The figures range from 400 on November 30, 1928 in a gym in Hersbruck to an estimated 100,000 on July 20, 1932 at the Victoria sports field in Hamburg, with an average of about 15,000 attendees. The problem of ignoring varying event size is, again, one of hidden variation of treatments. Larger events may have had stronger effects because they had reached a wider audience of voters and opinion leaders or because they had attracted more media attention, through which the campaign messages were promulgated to the wider public. Larger events could have also increased the intensity of spatial spillovers through both travel activities and local press coverage. Once again, additional analyses do not indicate any systematic differences among events with less than 5,000; 5,000-20,000: more than 20,000 attendees; and of unknown event size, respectively. In a related manner, we also looked for differences across counties with eligible voting populations of less than 20,000; 20,000-50,000; 50,000-

${ }^{18}$ Due to the decreased number of events per category, we had to pool observations across elections. We included an additional set of fixed effects ("diff-in-diff-in-diff") to account for election-specific heterogeneity. 
80,000; and more than 80,000 - again without any notable differences. The detailed results are reported in Tables I 23 to I34 as well as Table I35 in the Appendix.

\section{Causal Transience}

Our difference-in-differences estimation hinges on the causal transience assumption, namely that the electoral response to a Hitler visit in a given period is not affected by prior visits in that area (see Holland, 1986). This assumption is particularly critical since our propensity score model includes previous Hitler appearances among the predictors to account for unobserved factors which guided targeting decisions. Therefore, chances are that we end up matching previously visited exposure areas with previously visited controls. If visits had their intended electoral effect, but this effect was non-transient in time and non-cumulative over repeated events (see the preceding section), then we would underestimate the effect of current events. While our earlier findings in connection with the 1932 presidential election do not point towards persistent effects, an additional matching analysis in which we exclude areal units that had already been exposed to Hitler appearances in the preceding election period provides a more direct check for the credibility of causal transience. As previous appearance is a powerful predictor of current appearance, most of the excluded matches come from the high- and intermediate-propensity domain (see Figure I5 in the Appendix). Figure 6 contrasts effect estimates from this analysis (in black) with our main results (in grey) from Figure 4. The 1932 presidential runoff had to be altogether excluded from the comparison since Hitler had already visited all but one of the 21 venues previously. Naturally, the elimination of matched pairs involving previously visited areas leads to wider confidence bands, but there are no notable differences to our main findings beyond this. This result lends some tentative support for causal transience to hold.

\section{Dynamic Campaign Strategies}

It is a small step from the instrumental actors perspective, which guides the selection of covariates for the propensity score model, to the notion of dynamic strategies, according to which candidates continuously adapt their actions in response to campaign events and opponents' actions. To take an example, Plöckinger $(1999,73-77)$ reports increased activity of local NSDAP organizations and their foes ahead of Hitler's visits-leafleting on both sides, bill-posting and over-painting, and sabotage-which may have all affected the vote in different ways. Blackwell (2013) exposes the problem of one-shot methods for causal inference to separate actions from reactions. This distinction is important since causes of the actions of interest (i.e. Hitler speeches) are relevant confounders to be taken care of when assessing their causal effect, while conditioning on the consequences of these actions 'controls away' relevant indirect parts of their effect. A solution to this problem is to investigate the effect of an action sequence on an outcome using methods for dynamic 
Figure 6: Difference-in-differences estimates of exposure effects on NSDAP vote shares, KPD vote shares, and turnout in national parliamentary elections 1930-33. Lines represent $80 \%$ and $95 \%$ confidence bands. Estimates are reported with previously visited areas included and excluded. For full model statistics, see Tables I36 to I38 in the Appendix.

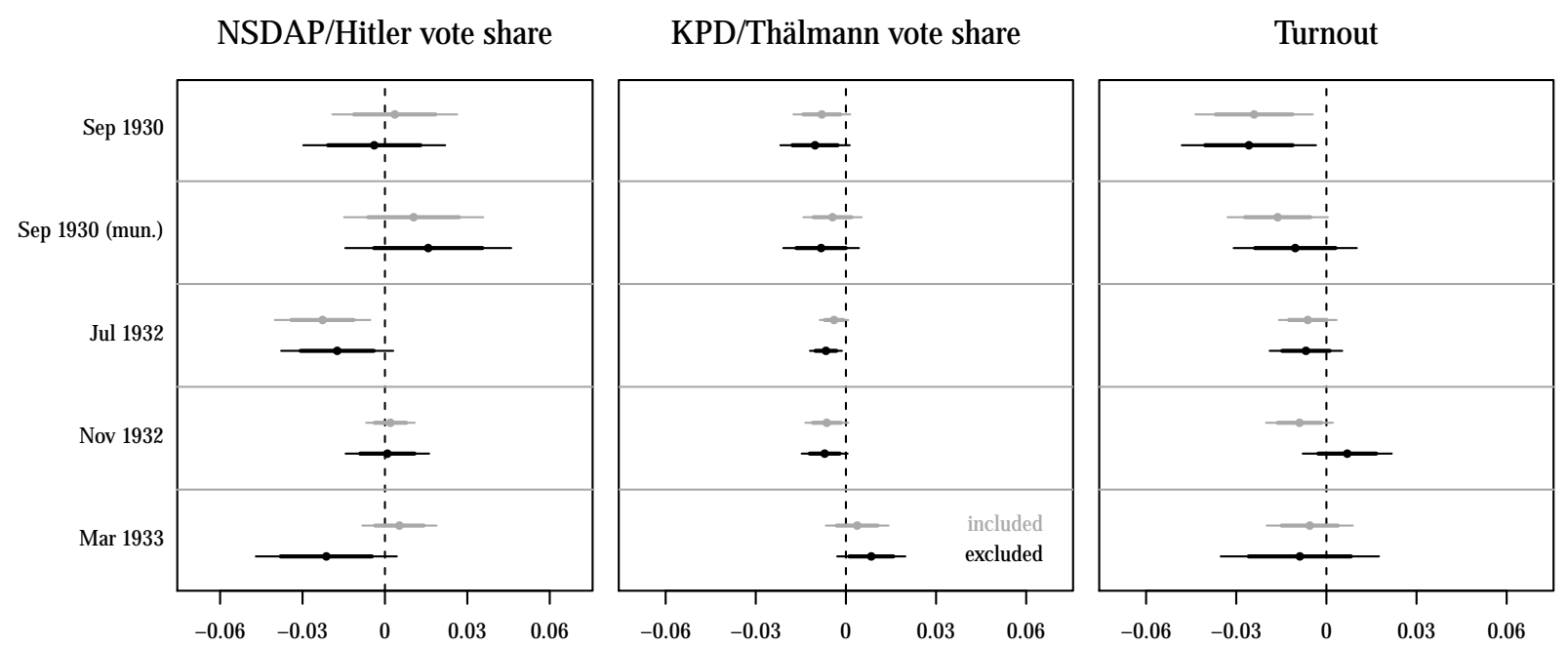

causal inference (Robins, Hernán and Brumback, 2000). Unfortunately, we do not have any nationwide information about the campaign activities of other parties and candidates, much less about seemingly spontaneous actions as those reported above. ${ }^{19}$ Therefore, our analysis-thus far tacitly-proceeded on the assumption that while Hitler might have re-calibrated the content of his speeches in response to campaign events and opponent actions, his itinerary had been fixed at the beginning of a campaign. Several entries in chief strategist Goebbels' (1992) diaries suggest this was actually the case. If, on the other hand, Hitler's speeches provoked counteractions by opposing parties or back-up measures by supporters in the manner reported by Plöckinger (1999), we would still be able to conclude that the overall effects of Hitler's appearances were essentially zero. Yet another threat to valid inference would arise if 'regular' campaign events organized by local branches of the Nazi party and Hitler visits were planned in a complementary fashion which would have lead to their purportedly positive effects cancelling each other out in the analysis. However, the event calendars of the Lippe campaign in December 1932 and January 1933 published in Ciolek-Kümper (1976, 313-317) suggest that Hitler's appearances were normally scheduled in addition to the list of district or regional speakers.

\footnotetext{
${ }^{19} \mathrm{Ohr}$ (1997) collected regional data about Nazi campaign activities from police reports for 224 Hessian communities from 1930 to 1932. Unfortunately, there had not been a single Hitler appearance in any of these communities during the period considered. An assessment of the sequence of various parties' activities and Hitler appearances is therefore infeasible.
} 
In any case, it is important to keep in mind that we are examining the effect of Hitler's appearances on top of other campaign activities by the Nazis and their competitors. The lack of data on these activities inevitably needs to be compensated with-hopefully plausible, but at the very least explicit—assumptions about their targeting.

\section{Conclusion}

Our empirical analysis suggests that Hitler's speeches as the Nazis' chief campaign tool at the end of the Weimar Republic were rationally targeted toward populous, competitive, and accessible areas, yet their electoral effects were modest at best and of limited geographical and temporal scope. The only significantly positive effect occurred with the 1932 presidential runoff-an election preceded by an extraordinarily short, intense, and one-sided campaign. The effect was far too feeble, however, to swing the election in Hitler's favor.

This result is particularly remarkable evidence for a qualified view of the effectiveness of election campaigns to manipulate the public (e.g., Campbell, 2008; Gelman and King, 1993; Popkin, 1991) since several important ingredients that are commonly claimed to create communication environments conducive to substantive campaign effects were present at the time: Hitler relied heavily on personal appearances, even today considered by campaign practitioners as one of the most potent ways for candidates to directly shape public opinion while avoiding the often negative tone of the media (Althaus, Nardulli and Shaw, 2002; Faucheux, 2002); local party organizations to support the campaign developed rapidly (Anheier, 2003; Flint, 2000); Hitler is generally considered a charismatic leader and consummate campaigner (Willner, 1985); the manipulative techniques employed were novel and sophisticated (Paul, 1990); and the use of modern technology, such as aircraft and loudspeakers, guaranteed Hitler an unparalleled geographic penetration and public attention (Plöckinger, 1999).

To be sure, campaign effects on voting behavior and election results are notoriously difficult to detect in a campaign realm that is characterized by the selective exposure of voters to a diffuse stream of conflicting messages (Bartels, 1993; Finkel, 1993; Zaller, 1992). The non-availability of individual-level exposure and outcome data certainly exacerbate our effort. On the other hand, there are some distinctive circumstances which supposedly facilitate the assessment of campaign effects in our empirical case: Hitler's campaign far exceeded any of his rivals' efforts, and unbalanced campaigns facilitate the identification of net effects (Iyengar and Simon, 2000). Moreover, the hostility of the public media toward Hitler, the low circulation figures of the NSDAP's own national paper, and a territorially fragmented newspaper landscape should have, to some extent, safeguarded our analysis against potential spillover effects that often threaten the validity of spatial ecological studies of candidate appearances. Therefore, we are fairly confident that our failure to find consistent evidence of campaign effects on voting behavior in what appears to be 
one of the most likely historical cases indeed provides evidence of their absence. This, of course, does not imply that Hitler's campaign activities were ineffective with respect to other goals, such as fund-raising (Goebbels, 1992), canvassing for new party members (Bytwerk, 1981), or simply enhancing an energetic party image (Allen, 1984).

Still, many historians tend to simply infer the effectiveness of Hitler's speeches and other tools of early Nazi propaganda based on the NSDAP's surge at the polls. As Kershaw $(2014,180)$ puts it, "studies of propaganda have generally been premised upon the implicit or explicit notion that Nazi propaganda [... ] was a success story." Scholars, mostly economists, have only recently begun to revisit the issue with novel data and inventive research strategies. However, while evidence of strong and long-lasting effects on collective perceptions, attitudes, and behaviors of Nazi propaganda under the dictatorship is now accumulating (Adena et al., 2015; Voigtländer and Voth, 2014, 2015), our examination of the crucial years leading up to the Nazi seizure of power casts doubt on the omnipotence of Nazi propaganda and Hitler's oratory in particular. Evidently the NSDAP's propaganda machinery took its full effect only after the Nazis had begun to gain totalitarian control over the state apparatus, societal organizations, and the emerging mass media (also see Adena et al., 2015).

The notion that charismatic leaders are of particular importance for the electoral success of right-wing populist parties has recently regained attention (e.g. Eatwell, 2000; Kitschelt and McGann, 1997; Mény and Surel, 2002). Our empirical findings support a skeptical view (also see van der Brug and Mughan, 2007). The mystification of the powers of demagogues seems just as inappropriate now as it was then. To do so overlooks the economic and political circumstances under which they succeed electorally: mass unemployment and economic despair (Falter, 1991; King et al., 2008), lack of support for democracy among elites and the public (Almond and Verba, 1963), popular detachment from established parties and their representatives (Shively, 1972), and weak institutions (Myerson, 2004; Shugart and Carey, 1992). 


\section{References}

Abadie, Alberto. 2005. "Semiparametric difference-in-differences estimators." Review of Economic Studies 72(1):1-19.

Abel, Theodore. 1965. The Nazi Movement. New York: Atherton Press.

Adena, Maja, Ruben Enikolopov, Maria Petrova, Veronica Santarosa and Ekaterina Zhuravskaya. 2015. "Radio and the rise of the Nazis in Prewar Germany." The Quarterly Journal of Economics 130(4):1885-1939.

Allen, William S. 1984. The Nazi Seizure of Power. The Experience of a Single German Town 1992-1945. New York: Penguin.

Almond, Gabriel Abraham and Sidney Verba. 1963. The civic culture: Political attitudes and democracy in five nations. Princeton: Princeton University Press.

Althaus, Scott L., Peter F. Nardulli and Daron R. Shaw. 2002. "Candidate appearances in presidential elections, 1972-2000." Political Communication 19(1):49-72.

Angrist, Joshua D., Guido W. Imbens and Donald B. Rubin. 1996. "Identification of Causal Effects Using Instrumental Variables." Journal of the American Statistical Association 91(434):444-455.

Anheier, Helmut K. 2003. Movement development and organizational networks: the role of 'single members' in the German Nazi party, 1925-30. In Social movements and networks. Relational approaches to collective action, ed. Mario Diani and Doug McAdam. Oxford: Oxford University Press pp. 49-76.

Anheier, Helmut K., Friedhelm Neidhardt and Wolfgang Vortkamp. 1998. "Movement cycles and the Nazi party activities of the Munich NSDAP, 1925-1930." American Behavioral Scientist 41(9):1262-1281.

Bartels, Larry M. 1985. "Resource allocation in a presidential campaign." Journal of Politics 47(3):928-936.

Bartels, Larry M. 1993. "Messages received: the political impact of media exposure." American Political Science Review 87(2):267-285.

Bennett, W. Lance and Shanto Iyengar. 2008. "A new era of minimal effects? The changing foundations of political communication." Journal of Communication 58(4):707-731.

Berelson, Bernard R., Paul F. Lazarsfeld and William N. McPhee. 1954. Voting: A study of opinion formation in a presidential election. Chicago: University of Chicago Press.

Blackwell, Matthew. 2013. "A framework for dynamic causal inference in political science." American Journal of Political Science 57(2):504-520. 
Brams, Steven J. and Morton D. Davis. 1974. "The 3/2's Rule in Presidential Campaigning." American Political Science Review 68(1):113-134.

Bruppacher, Paul. 2012. Adolf Hitler und die Geschichte der NSDAP. Teil 1: 1889 bis 1937. 3rd ed. Books on Demand.

Brustein, William. 1998. The logic of evil. The social origins of the Nazi party, 1925-1933. New Haven: Yale University Press.

Bytwerk, Randall L. 1981. "Fritz Reinhardt and the Rednerschule der NSDAP." Quarterly Journal of Speech 67(3):298-309.

Caliendo, Marco and Sabine Kopeinig. 2008. "Some practical guidance for the implementation of propensity score matching." Journal of Economic Surveys 22(1):31-72.

Campbell, Angus, Philip E Converse and Warren E Miller. 1960. The American Voter. New York: Wiley.

Campbell, James E. 2008. The American campaign. U.S. presidential campaigns and the national vote. 2 ed. College Station: Texas A\&M University Press.

Childers, Thomas and Eugene Weiss. 1990. "Voters and violence. Political violence and the limits of National Socialist mass mobilization." German Studies Review 13(3):481-498.

Ciolek-Kümper, Jutta. 1976. Wahlkampf in Lippe. München: Verlag Dokumentation.

Colantoni, Claude S., Terrence J. Levesque and Peter C. Ordeshook. 1975. “Campaign resource allocations under the Electoral College." American Political Science Review 69(1):141-154.

Collier, Rex Madison. 1944. "The effect of propaganda upon attitude following a critical examination of the propaganda itself." The Journal of Social Psychology 20(1):3-17.

Cox, Gary W. 1999. "Electoral rules and the calculus of mobilization." Legislative Studies Quarterly 24(3):387-419.

Domarus, Max. 1973. Hitler. Reden und Proklamationen, 1932-1945. Wiesbaden: Löwit.

Eatwell, Roger. 2000. "The rebirth of the 'extreme right' in Western Europe?" Parliamentary Affairs 53(3):407-425.

Evans, Richard J. 2005. The coming of the Third Reich. New York: Penguin.

Falter, Jürgen W. 1991. Hitlers Wähler. München: C.H. Beck.

Falter, Jürgen W. and Dirk Hänisch. 1990. "Election and Social Data of the Districts and Municipalities of the German Empire from 1920 to 1933." GESIS Data Archive, Cologne. ZA8013 Data file Version 1.0.0. URL: http://dx.doi.org/10.4232/1.8013 
Falter, Jürgen W. and Michael H. Kater. 1993. "Wähler und Mitglieder der NSDAP. Neue Forschungsergebnisse zur Soziographie des Nationalsozialismus 1925-1933." Geschichte und Gesellschaft 19(2):155-177.

Faucheux, Ronald A. 2002. Running for Office. The Strategies, Techniques, and Messages Modern Political Candidates Need to Win Elections. Lanham: M. Evans.

Finkel, Steven E. 1993. "Reexamining the "Minimal Effects" Model in Recent Presidential Campaigns." Journal of Politics 55(1):1-21.

Flint, Colin. 2000. "Electoral geography and the social construction of space: The example of the Nazi party in Baden, 1924-1932." GeoJournal 51(3):145-156.

Führer, Karl Christian. 2008. "Politische Kultur und Journalismus: Tageszeitungen als politische Akteure in der Krise der Weimarer Republik 1929-1933." Jahrbuch für Kommunikationsgeschichte pp. 26-51.

Gelman, Andrew and Gary King. 1993. "Why Are American Presidential Election Campaign Polls so Variable When Votes Are so Predictable?" British Journal of Political Science 23:409-451.

Gerber, Alan S. and Donald P. Green. 2000. "The effects of canvassing, telephone calls, and direct mail on voter turnout. A field experiment." American Political Science Review 94(3):653-663.

Goebbels, Joseph. 1992. Tagebücher 1924-1945. München: Piper.

Goldstein, Kenneth M. and Matthew Holleque. 2010. Getting up off the canvass. Rethinking the study of mobilization. In The Oxford Handbook of American Elections and Political Behavior, ed. Jan E. Leighley. Oxford: Oxford University Press pp. 577-594.

Google Inc. 2015. “Google Maps API.” URL: https://developers.google.com/maps/

Grofman, Bernard and Peter Selb. 2009. "A fully general index of political competition." Electoral Studies 28(2):291-296.

Hadamovsky, Eugen. 1933. Propaganda und nationale Macht. Die Organisation der öffentlichen Meinung für die nationale Politik. Oldenburg: Gerhard Stalling.

Hänisch, Dirk. 1989. "Inhalt und Struktur der Datenbank 'Wahl- und Sozialdaten der Kreise und Gemeinden des Deutschen Reiches von 1920 bis 1933'." Historical Social Research 14(1):39-67.

Heberle, Rudolf. 1978. Bestimmungsgründe für die Wahlerfolge der NSDAP in SchleswigHolstein 1924 bis 1932. In Wählerbewegung in der deutschen Geschichte. Analysen und Berichte zu den Reichstagswahlen 1871-1931, ed. Otto Büsch, Monika Wölk and Wolfgang Wölk. pp. 261-297. 
Heckman, J. J., H. Ichimura and P.E. Todd. 1997. “Matching as an Econometric Evaluation Estimator: Evidence from Evaluating a Job Training Programme." The Review of Economic Studies 64(4):605-654.

Herr, Paul J. 2002. "The impact of campaign appearances in the 1996 election." Journal of Politics 64(3):904-913.

Hill, Jeffrey S., Elaine Rodriquez and Amanda E. Wooden. 2010. "Stump speeches and road trips. The impact of state campaign appearances in presidential elections." Political Science and Politics 43(2):243-254.

Hillygus, D. Sunshine. 2010. Campaign Effects on Vote Choice. In Oxford Handbook on Elections and Political Behavior, ed. Jan Leighly and George C. Edwards III. Oxford: Oxford University Press. pp. 326-345.

Hitler, Adolf. 1992. Hitler. Reden, Schriften, Anordnungen. Vom Weimarer Parteitag bis zur Reichstagswahl. Juli 1926 - Mai 1928. Vol. 2.1 München: K.G. Saur.

Hitler, Adolf. 1994a. Hitler. Reden, Schriften, Anordnungen. Von der Reichstagswahl bis zur Reichspräsidentenwahl. Oktober 1930 - März 1932. Vol. 4.1 München: K.G. Saur.

Hitler, Adolf. 1994b. Hitler. Reden, Schriften, Anordnungen. Zwischen den Reichstagswahlen. Juli 1928 - September 1930. Vol. 3.1 München: K.G. Saur.

Hitler, Adolf. 1994c. Hitler. Reden, Schriften, Anordnungen. Zwischen den Reichstagswahlen. Juli 1928 - September 1930. Vol. 3.2 München: K.G. Saur.

Hitler, Adolf. 1995. Hitler. Reden, Schriften, Anordnungen. Zwischen den Reichstagswahlen. Juli 1928 - September 1930. Vol. 3.3 München: K.G. Saur.

Hitler, Adolf. 1996. Hitler. Reden, Schriften, Anordnungen.Von der Reichspräsidentenwahl bis zur Machtergreifung. April 1932 - Januar 1933. Vol. 5.1 München: K.G. Saur.

Hitler, Adolf. 1997. Hitler. Reden, Schriften, Anordnungen. Von der Reichstagswahl bis zur Reichspräsidentenwahl. Oktober 1930 - März 1932. Vol. 4.3 München: K.G. Saur.

Hitler, Adolf. 1998. Hitler. Reden, Schriften, Anordnungen. Von der Reichspräsidentenwahl bis zur Machtergreifung. April 1932 - Januar 1933. Vol. 5.2 München: K.G. Saur.

Holbrook, Thomas M. 2002. “Did the whistle-stop campaign matter?" Political Science and Politics 35(1):59-66.

Holland, Paul W. 1986. "Statistics and causal inference." Journal of the American Statistical Association 81(396):945-960.

Huber, Gregory A. and Kevin Arceneaux. 2007. "Identifying the persuasive effects of presidential advertising." American Journal of Political Science 51(4):957-977. 
Imbens, Guido W. 2000. "The role of the propensity score in estimating dose-response functions." Biometrika 87(3):706-710.

Iyengar, Shanto and Adam F. Simon. 2000. "New Perspectives and Evidence on Political Communication and Campaign Effects." Annual Review of Psychology 51:149-169.

Iyengar, Shanto and Donald R. Kinder. 1987. News that matters. Television and American opinion. Chicago: University of Chicago Press.

Janssen, Karl-Heinz. 1985. "Kümmerliche Notizen. Rauschnings „Gespräche mit Hitler": Wie ein Schweizer Lehrer nach 45 Jahren einen Schwindel auffliegen ließ.” URL: http://www.zeit.de/1985/30/kuemmerliche-notizen

Johnston, Richard, André Blais, Henry E. Brady and Jean Crête. 1992. Letting the people decide. The dynamics of Canadian elections. Stanford, CA: Stanford University Press.

Jones, Jeffrey M. 1998. "Does bringing out the candidate bring out the votes? The effects of nominee campaigning in Presidential elections." American Politics Quarterly 26(4):395419.

Kater, Michael H. 1980. Methodologische Überlegungen über Möglichkeiten und Grenzen einer Analyse der sozialen Zusammensetzung der NSDAP von 1925 - 1945. In Die Nationalsozialisten. Analysen faschistischer Bewegung, ed. Reinhard Mann. Stuttgart: KlettCotta. pp. 155-185.

Katz, Elihu and Paul Lazarsfeld. 1955. Personal influence: The part played by people in the flow of mass communications. New York: The Free Press.

Kelley, Stanley. 1961. The Presidential campaign. In The Presidential election and transition, 1960-1961: Brookings lectures and additional papers, ed. Paul T. David. Brookings Institution. pp. 57-87.

Kershaw, Ian. 2014. How effective was Nazi propaganda? In Nazi propaganda. The power and limitations, ed. David Welch. London: Routledge pp. 180-205.

King, David C. and David Morehouse. 2004. Moving voters in the 2000 presidential campaign. Local visits, local media. In Lights, camera, campaign! Media, politics and political advertising, ed. David A. Schultz. New York: Peter Lang pp. 301-318.

King, Gary, Ori Rosen, Martin Tanner and Alexander F. Wagner. 2008. “Ordinary economic voting behavior in the extraordinary election of Adolf Hitler." Journal of Economic History 68(4):951-996.

Kitschelt, Herbert and Anthony J McGann. 1997. The radical right in Western Europe: A comparative analysis. Ann Arbor: University of Michigan Press.

Klapper, Joseph T. 1960. The Effects of Mass Communication. Glencoe, Ill.: The Free Press. 
Layton, Roland V. 1970. “The Völkischer Beobachter, 1920-1930: The Nazi Party Newspaper in the Weimar Era." Central European History 3(4):353-382.

Lazarsfeld, Paul F., Bernard Berelson and Hazel Gaudet. 1948. The people's choice. How the voter makes up his mind in a presidential campaign. New York: Columbia University Press.

Mény, Yves and Yves Surel. 2002. The constitutive ambiguity of populism. Springer.

Myerson, Roger B. 2004. "Political economics and the Weimar disaster." Journal of Institutional and Theoretical Economics 160(2):187-209.

Oakes, J Michael. 2004. "The (mis-)estimation of neighborhood effects: causal inference for a practicable social epidemiology." Social Science \& Medicine 58(10):1929-1952.

Ohr, Dieter. 1997. Nationalsozialistische Propaganda und Weimarer Wahlen. Empirische Analysen zur Wirkung von NSDAP-Versammlungen. Wiesbaden: Springer.

O'Loughlin, John, Colin Flint and Luc Anselin. 1994. "The geography of the Nazi vote. Context, confession, and class in the Reichstag election of 1930." Annals of the Association of American Geographers 84(3):351-380.

O'Loughlin, John and Michael Shin. 1995. "Regions and milieux in Weimar Germany. The Nazi party vote of 1930 in geographic perspective." Erdkunde 49(4):305-314.

Paul, Gerhard. 1990. Aufstand der Bilder. Die NS-Propaganda vor 1933. Bonn: J.H.W. Dietz Nachf.

Plöckinger, Othmar. 1999. Reden um die Macht? Wirkung und Strategie der Reden Adolf Hitlers im Wahlkampf zu den Reichstagswahlen am 6. November 1932. Wien: Passagen .

Popkin, Samuel L. 1991. The reasoning voter: Communication and persuasion in presidential campaigns. Chicago: University of Chicago Press.

Pridham, Geoffrey. 1973. Hitler's Rise to Power: The Nazi Movement in Bavaria, 1923-1933. London: Hart-Davis, MacGibbon.

Pyta, Wolfram. 2007. Hindenburg. München: Siedler.

Rauschning, Hermann. 1939. Hitler Speaks. A Series of Political Conversations with Adolf Hitler on his Real Aims. London: Thornton Butterworth.

Reuband, Karl-Heinz. 2006. “Das NS-Regime zwischen Akzeptanz und Ablehnung. Eine retrospektive Analyse von Bevölkerungseinstellungen im Dritten Reich auf der Basis von Umfragedaten (The Nazi Regime between Acceptance and Refusal. A Retrospective Analysis of Popular Opinion in the Third Reich, Based on Survey Data)." Geschichte und Gesellschaft pp. 315-343. 
Ridgeway, Greg, Stephanie A. Kovalchik, Beth A. Griffin and Mohammed U. Kabeto. 2015. "Propensity score analysis with survey weighted data." Journal of Causal Inference 3(2):237-249.

Robins, James M, Miguel Angel Hernán and Babette Brumback. 2000. "Marginal Structural Models and Causal Inference in Epidemiology." Epidemiology 11(5):550-560.

Rösch, Mathias. 2002. Die Münchner NSDAP 1925-1933: Eine Untersuchung zur inneren Struktur der NSDAP in der Weimarer Republik. München: Oldenbourg.

Rosenstone, Steven J. and John Mark Hansen. 1993. Mobilization, Participation, and Democracy in America. London: Macmillan.

Rubin, Donald B. 1980. "Randomization Analysis of Experimental Data. The Fisher Randomization Test: Comment." Journal of the American Statistical Association 75(371):591593.

Schanbacher, Eberhard. 1982. Parlamentarische Wahlen und Wahlsystem in der Weimarer Republik. Wahlgesetzgebung und Wahlreform im Reich und in den Ländern. Düsseldorf: Droste.

Schneider-Haase, D. Torsten. 1991. "Beschreibung der Stichprobenziehung zu den Mitgliedern der NSDAP vom 27. März - 7. September 1989 im Berlin Document Center." Historical Social Research 16(3):113-151.

Sellers, Patrick J and Laura M Denton. 2006. "Presidential visits and midterm senate elections." Presidential Studies Quarterly 36(3):410-432.

Shaw, Daron R. and James G. Gimpel. 2012. "What if we randomize the governor's schedule? Evidence on campaign appearance effects from a Texas field experiment." Political Communication 29(2):137-159.

Shively, W Phillips. 1972. "Party identification, party choice, and voting stability: the Weimar case." American Political Science Review 66(4):1203-1225.

Shugart, Matthew S. and John M. Carey. 1992. Presidents and assemblies. Constitutional design and electoral dynamics. Cambridge, UK: Cambridge University Press.

Stachura, Peter D. 1980. “The political strategy of the Nazi party, 1919-1933." German Studies Review 3(2):261-288.

Thurner, Paul W., André Klima and Helmut Küchenhoff. 2015. "Agricultural structure and the rise of the Nazi Party reconsidered." Political Geography 44:50-63.

van der Brug, Wouter and Anthony Mughan. 2007. "Charisma, Leader Effects and Support for Right-Wing Populist Parties." Party Politics 13(1):29-51. 
Vavreck, Lynn, Constantine J. Spiliotes and Linda L. Fowler. 2002. "The effects of retail politics in the New Hampshire primary." American Journal of Political Science 46(3):595610.

Voigtländer, Nico and Hans-Joachim Voth. 2014. "Highway to Hitler." NBER Working Paper No. 20150.

Voigtländer, Nico and Hans-Joachim Voth. 2015. "Nazi indoctrination and anti-semitic beliefs in Germany." Proceedings of the National Academy of Sciences of the United States of America 112(26):7931-7936.

Wakefield, Jonathan. 2004. "A critique of statistical aspects of ecological studies in spatial epidemiology." Environmental and Ecological Statistics 11(1):31-54.

Watt, James H., Mary Mazza and Leslie Snyder. 1993. "Agenda-setting effects of television news coverage and the effects decay curve." Communication Research 20(3):408-435.

Wernette, Dee R. 1974. "Political Violence and German Elections: 1930 und July, 1932." Dissertation, University of Michigan.

Willner, Ann Ruth. 1985. The spellbinders: Charismatic political leadership. New Haven: Yale University Press.

Zaller, John. 1992. The nature and origins of mass opinion. Cambridge, UK: Cambridge University Press. 